\title{
The glory-motif in John 17:1-5: An exercise in Biblical semantics
}

\author{
D G van der Merwe
}

(Vista University)

\section{ABSTRACT}

\section{The glory-motif in John 17:1-5: An exercise in Biblical semantics}

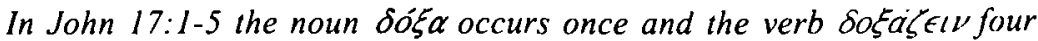
times. They are consequently translated as 'glory' and 'glorification' in various Bible translations. This research is an attempt to determine the various perspectives and possible semantic meanings respectively of these words in order to suggest meaningful alternatives that could be used in a dynamic-equivalent or periphrastic translation. The methodology followed is: first a look at a few lexical meanings, and an investigation of the textual and theological contexts in order to help determine the basic semantic fields of these words, followed by a more detailed examination to aid a more specific interpretation. In the detailed exami-

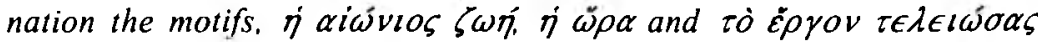
play important semantic roles as theological settings from which the

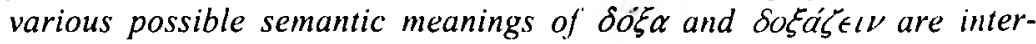
preted.

\section{INTRODUCTION}

The Greek words $\delta$ ó $\xi \alpha$ (noun) and $\delta \circ \xi a ́ \zeta \epsilon \iota \nu$ (verb), translated in English as 'glory' and 'glorify', cover a wide range of meaning. In most other languages no single word is able to express the full meaning of either one of these words in all their various uses. Even the many English translations offer little help in finding the best equivalents for the New Testament words in other languages. This is due to the common use of 'glory' or 'glorify' in most of the places where either $\delta \delta \xi \alpha$ or $\delta 0 \xi \alpha$ $\zeta \epsilon \iota \nu$ is found.

Although much has been written on the $\delta$ ó $\xi \alpha$ motif in the Fourth Gospel in theological dictionaries, commentaries and articles, the coverage of how this motif occurs in John 17:1-5 is inadequate and fragmentary. Where this motif has been discussed in connection with the Fourth Gospel it is either about the 'glory' of Jesus (Painter 1975: 50ff; Ibuki 1988:38ff; Bratcher 1991:401ff) or the 'glory' of God (Caird 1969:265ff), or 'glory' in the Fourth Gospel in general (Cook 1984: $291 \mathrm{ff}$, with little attention being paid to John 17:1-5, where the glory of Jesus and of God complement one another. 
This research is aimed above all at determining the various perspectives and possible semantic meanings of $\delta \delta^{\prime} \xi \alpha$ and $\delta 0 \xi \alpha \dot{\zeta} \epsilon L \nu$, as used in John 17:1-5, in order to suggest a possible meaningful translation of these verses in dynamic-equivalent or periphrastic translations. When the essence of a glorifying event is determined, $\delta o \delta \alpha$ and $\delta \circ \xi \alpha \dot{\alpha} \epsilon t \nu$ can be substituted by a description of the essence in order to make the translation more meaningful for the reader.

To understand the specific meanings of $\delta o \delta \alpha$ and $\delta o \xi \alpha \dot{\alpha} \zeta L \nu$ in the immediate context of John 17:1-5, we will first have to look at a few proposed lexical meanings, the textual context and the theological context of the Fourth Evangelist in order to help determine the basic semantic fields of these words, before conducting a closer examination of the

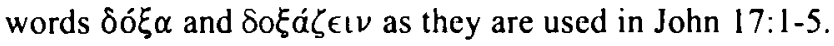

\section{THE POSSIBLE RANGE OF MEANINGS OF $\triangle O \Xi A$ AND $\triangle(O E A Z E I N$ IN TIE NEW TESTAMENT}

According to The Greek-English Lexicon (Liddell \& Scott 1974:178) the lexical meaning of $\delta o ́ \xi \alpha$ is 'honour', 'glory' and 'splendour', and that of $\delta o \xi a \zeta \in \in V$ is 'to glorify' or 'extol'. The Greek-English Lexicon of the New Testament and other Early Christian Literature (Danker 2000:257f) translates $\delta o ́ \xi \alpha$ as (1) the condition of being bright or shining, 'brightness', 'splendor', 'radiance'; (2) a state of being magnificent, 'greatness', and 'splendor'; (3) honour as enhancement or recognition of status or performance, 'fame', 'recognition', 'renown', 'honour', 'prestige'; (4)

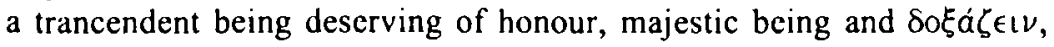
as to (1) influence one's opinion about another so as to enhance the latter's reputation, 'praise', 'honour', 'extol', or (2) to cause to have splendid greatness, 'clothe in splendor' and 'glorify'.' Louw \& Nida's (1988:66) semantic lexicon has eleven different semantic domains under which they classify $\delta o ́ \xi \alpha$ : 'splendour', 'brightness', 'amazing might', 'praise', 'honour', 'greatness', 'glorious being', 'heaven', 'pride', including the idiom 'give glory to God' in John 9:24, and 'swear', 'put under oath', 'vow'; and three domains for $\delta \circ \xi \alpha$ $\zeta \in t \nu:$ 'praise', 'honour', 'glorify'.

${ }^{\prime}$ Fry links up with Danker. According to him (1976:4221) there are three main components of meaning of the word 'glory', as it is used in the New Testament to refer to the glory of God or Christ. They are: (1) brightness or splendour; (2) great power and strength; (3) majesty and honour. Bratcher (1991:401f) adds another meaning, 'divine nature' or 'divinity' or 'God-likeness', as a possible meaning and translation of $\delta o ́ \xi \alpha$ in many passages of the Fourth Gospel. These possible meanings then relate to God and Christ's position or status (majesty/honour); presence (brightness/splendour); divine action (power/strength) and nature (divinity). 
The Theological Dictionary of the New Testament (Kittel 1978: 247) interprets $\delta o ́ \xi \alpha$ as 'divine honour', 'divine splendour', 'divine power' and 'visible divine radiance'. According to Kittel these meanings are fluid and can only be distinguished artificially. $\mathrm{He}$ translates $\delta o \xi \dot{\alpha} \zeta \epsilon t v$ as 'to honour' or 'to extol'. The Dictionary of the New Testament Theology (Aalen 1976:44) translates $\delta o ́ \xi \alpha$ as 'radiance', 'glory', 'repute', and $\delta o \xi a ́ \zeta \epsilon L v$ as 'praise', 'glorify'.

These lexical meanings reflect a number of combinations rendered by the $N I V, N A S B, K J V, N R S V, N K J V, N L V$, and the $N C V^{2}$ throughout the Fourth Gospel as 'praise', 'honour', 'glory' and 'glorify', while in John 17:1-5 $\delta o ́ \xi \alpha$ is translated as 'glory', and $\delta 0 \xi \alpha \zeta \in I V$ consistently as 'glorify'.

The consultation of these lexicons, on the one hand contributes to create a scope from which we can start to determine the possible semantic meanings of $\delta \dot{\delta} \xi \alpha$ and $\delta \circ \xi \dot{\alpha} \zeta \epsilon \mid \nu$ and, on the other hand, indicates how limited and one-sided the interpretations and translations of the words $\delta o ́ \xi \alpha$ and $\delta \circ \xi a ́ \zeta \epsilon เ \nu$ have been in the above-mentioned (and probably also other) Bible translations.

\section{$3 \quad \triangle O \equiv A$ AND $\triangle O E A Z E I N$ IN THE FOURTH GOSPEL}

The following is a brief indication of all the aspects linked with the $\delta$ ó $\xi \alpha$ theme in the Fourth Gospel (regardless of whether the noun $\delta \delta^{5} \alpha^{3}$ or the verb $\delta o \xi \dot{\alpha} \zeta \in v^{4}{ }^{4}$ is used). $\Delta o ́ \xi \alpha$ is used only once in connection with the Pharisees, who attach greater value to the praise of men more than to praise from God (12:43). It is also used once in connection with the disciples, who receive glory from Jesus $(17: 22)$. Once $\delta \delta \xi \alpha$ is used without any subject: glory comes from God $(5: 44) . \Delta \delta \xi \alpha$ is used 13 times $(9: 24 ; 11: 4,40 ; 12: 28 ; 13: 31 ; 14: 13 ; 15: 8 ; 17: 1,4 ; 21: 19)$ in connection with the 'glory of God', and 19 times $(1: 14 ; 2: 11 ; 7: 39 ; 8: 54$; $11: 4 ; 12: 16,23,41 ; 13: 31,32 ; 16: 14 ; 17: 1,5,10,22,24)$ in connection with the 'glory of Jesus'. The $\delta$ ó $\xi \alpha$ of God comes from the Jews $(9: 24)$, from the disciples $(15: 8 ; 21: 19)$, but especially from Jesus $(7: 18 ; 12: 28$ by implication; $13: 31,32 ; 17: 1,4)$. The $\delta \delta \delta \alpha$ of Jesus comes from his disciples (17:10), the Spirit (16:14), and the Father $(8: 54 ; 13: 31,32$;

$2 N I V$ (New International Version), NASB (Ncw American Standard Bible), KJV (King James Version), NRSV (New Revised Standard Version), NKJV (New King James Version), $N L V$ (New Living Version), $N L C$ (New Century Version). The $N L C$ added 'boasting' and 'glorious things'. The NASB and NRSV use only 'glory' and 'glorify'.

John $1: 14(2 x) ; 2: 11 ; 5: 41,44 ; 7: 18(2 x), 8: 50,54 ; 9: 24 ; 11: 4,40 ; 12: 41,43(2 x)$; 16:2;17:5,22,24.

4John 7:39; 8:54 (2x); 11:4,13;12:16,23,28(3x);13:31 (2x),32 (3x); 15:8; 16:14; $17: 1(2 x), 4,5 ; 21: 19$. 
$17: 1,5,24$; and $12: 41$ by implication), and from signs $(2: 11 ; 11: 4)$. In John 7:39, 12:16,23 and 17:1 Jesus' $\delta$ ó $\xi \alpha$ is clearly linked with his death. Finally, those who believe will see the $\delta \delta \delta \alpha$ of God (11:40), and the disciples of Jesus will see his $\delta$ ó $\xi \alpha(17: 24)$.

The possible semantic meanings and translations will however, be more narrowly determined by their context. Here 'context' refers to the immediate textual context of the Fourth Gospel, especially John 17:1-8, and the historical situation in which the word is used. Then there is also the context of the theological tradition, in which the evangelist stood to be considered.

\section{THE TEXTUAL CONTEXT FROM WHICH THE WORDS AOEA AND $\triangle O \Xi A Z E I N$ ARE TO BE INTERPRETED}

The Last Discourse in the Fourth Gospel is dominated by the theme of

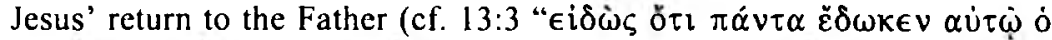

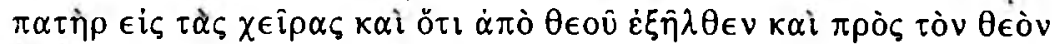
$\dot{v} \pi \dot{\alpha} \gamma \in \mathrm{l} ")$, and the preparation of his disciples for their task to continue his mission. As Jesus has completed his mission, with $\dot{\eta} \omega \dot{\omega} \rho \alpha$ at hand, he has to report ${ }^{5}$ to his sender concerning his completed mission ${ }^{6}$. When Jesus reports to his Father he does it in the form of the prayer found in Chapter 17:1-8. Here, very briefly, Jesus reflects on the past concerning what he has done and accomplished (by using mostly the aorist and perfect active indicative) in and through his divine mission. He clcarly states that he has 'glorified' the Father in fulfilling his mission' and wants also to be 'glorified' by the Father.

The following is a discourse analysis in order to determine the textual context and locality of the Greek words $\delta \delta \xi \alpha$ and $\delta \circ \xi \alpha \dot{\zeta} \epsilon t \nu$.

\footnotetext{
${ }^{5}$ On the grounds of the close relationship between Jesus and his Father any report seems redundant. But because the Father is in him and he in the Father ( $v 20)$, and even with the crucifixion still to come, Jesus can deliver this report.

${ }^{6}$ This idea that Jesus has completed the work the Father has given him, is an idea found again and again in the Fourth Gospel $(4: 34 ; 5: 36 ; 14: 31,17: 4$; cf. 19:30). The

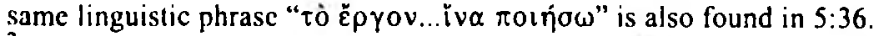

${ }^{7}$ Apart from the statement in 13:3 If (ó $0 \epsilon \hat{o} \zeta \dot{\varepsilon} \delta \circ \xi \dot{\alpha} \sigma \theta \eta \dot{\varepsilon} v \alpha \dot{\tau} \tau \hat{\varphi}$ ) there is no previous reference in the Fourth Gospel to the effect that Jesus has 'glorified' the Father by his work on earth. It is on this reference in $13: 31$ f that the petition that the Father may now glorify the Son depends. This $\delta \circ \xi a \zeta \epsilon \downarrow \nu$ is, however, implicit whenever Jesus refers to himself as 'doing the will of the one who sent him'.
} 


\subsection{Discourse analysis of John 17:1-5}

This report by Jesus can be divided into two sections: verses $1-5$ and verses $6-8$. The following is a discourse analysis of verses $1-5^{8}$.

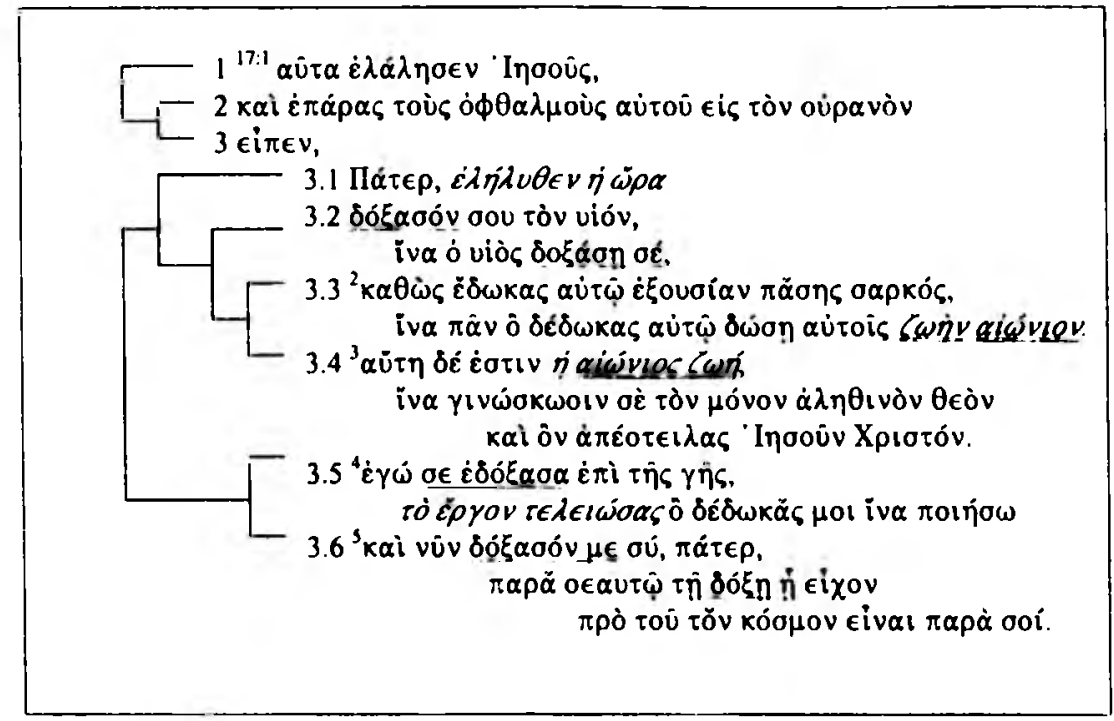

These verses form a separate unit within Chapter 17 by reason of the theme of glorification at its centre and its chiastic structure (Waldstcin 1990:320). The verb occurs 4 times (all in the aorist) and the noun only once to emphasize the achievement of glorification in the soteriological events. This repetitive texture of the verb $(\delta \circ \xi \dot{a} \zeta \epsilon t v)$ gives initial insight into the overall picture of this discourse (Robbins 1996:8). From this analysis the following chiastic pattern (cf Malatesta 1971:195f) is derived, which indicates how the glory motif is interwoven in these verses.

\footnotetext{
${ }^{8}$ The omission of a discourse analysis of vv 6-8 is due to the absence of $\delta \circ \xi a \zeta \epsilon t v$ in these verses, and because they can be regarded as an appendix to verses $1-5$. The discourse analysis of 17:1-5 has been done according to the principles developed by members of the New Testament Society of South Africa, based on the pioneering work of $\mathrm{J} P$ Louw since the late sixties.
} 


\begin{tabular}{|c|c|}
\hline A $\delta o ́ \xi \alpha \sigma o ́ v$ oou tòv vióv & \\
\hline B ó viòc ठoß & 7 \\
\hline 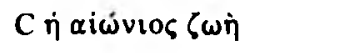 & \\
\hline$B^{\prime} \dot{\varepsilon} \gamma \omega \sigma \epsilon \dot{\varepsilon} \delta 0 ́ \xi \alpha \sigma \alpha$ & 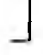 \\
\hline$A^{\prime} \delta o ́ \xi \alpha \alpha o o ́ v \mu \in$ oú & \\
\hline
\end{tabular}

\subsection{The interpretation of this chiastic pattern}

This chiastic pattern helps to interpret $\delta \circ \xi a \dot{\zeta} \epsilon t \nu$ from two different perspectives: the one where the Son is glorified $\left(A-A^{\prime}\right)$, the other the glorification of the Father (B-B'). This pattern indicates that the $\delta \circ \xi a$ a $\zeta \in v$

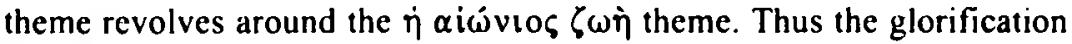
of the Father and of the Son has to be interpreted from the perspective of $\dot{\eta} \alpha i \omega v i o \zeta \zeta \omega \dot{\eta}$, which means that this perspective constitutes the main theological setting ${ }^{9}$ from which $\delta 0 \xi a ́ \zeta \epsilon t v$ is to be interpreted.

We will now look at the theological content and context that influenced the Fourth Evangelist in order to ascertain the theological perspectives, which will in the end influence the proposed interpretation and translation of the words $\delta \xi \xi \alpha$ and $\delta 0 \xi \alpha \zeta \epsilon \in$.

\footnotetext{
9 'Setting' refers to the theological environment from which a word or concept is to be interpreted, due to the influence the theological environment will have on the understanding and interpretation of that particular word or concept.
} 

$\triangle O \Xi A Z E I N$

5.1 A diagrammatic analysis of the theological content of the glorification in 17:1-8:

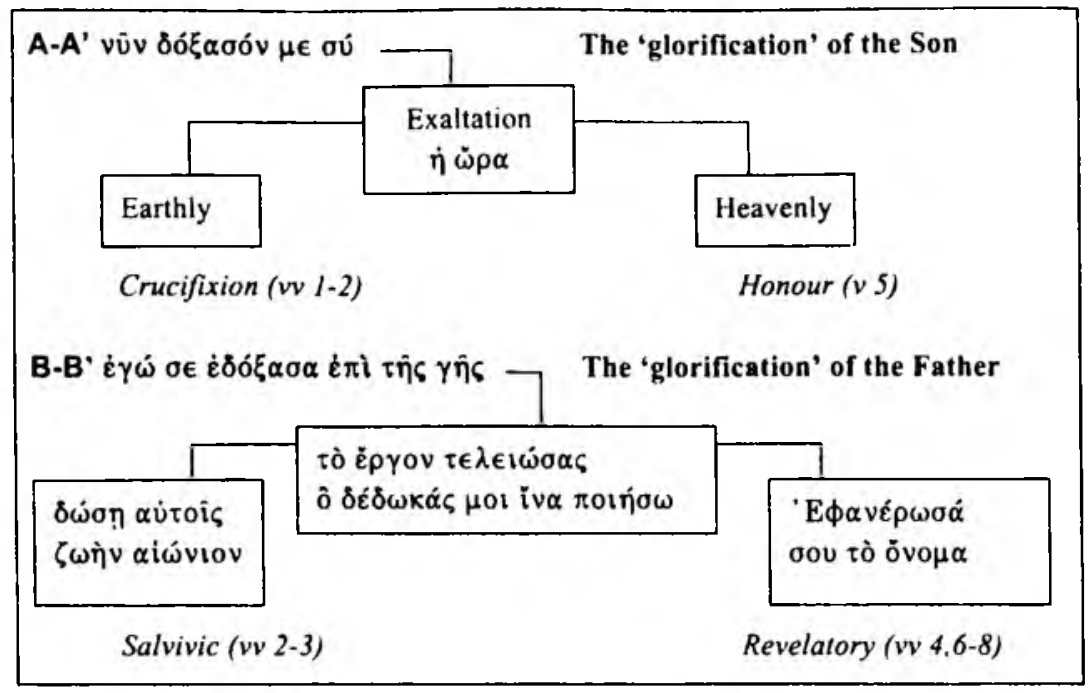

The following is a brief interpretation of the theological analysis of 'glorification', which will later be verified.

$\mathbf{A}-\mathbf{A}^{\prime}$ of the chiasm concerns the $\delta \circ \xi \alpha \zeta \in \mid \nu$ of the Son which, in verse 1 , centres around its theological goal, "iv $\alpha$ ó viòs $\delta \circ \xi \alpha$ á⿴囗十 $\sigma \dot{\varepsilon}$ ". Here the 'glorification' of the Son pertains his exaltation on the cross (and corresponds with $7: 30 ; 8: 20 ; 12: 23$ ), which refers to the beginning of his return to his Father. This 'glorification' of the Son is instrumental to the 'glorification' of the Father. In this striking salvation act the identities of both the Father and the Son are revealed. However, in verse 5 the $\delta \circ \xi \dot{\alpha} \zeta \epsilon L \nu$ of Jesus corresponds with that of the Father, because it relates to Jesus' pre-temporal existence with the Father in the world above (cf 17:24). Here Jesus' 'glorification' is more closely defined by the noun $\delta$ ó $\xi \alpha^{10}$ in the same verse (v 5).

B-B' of the chiasm concerns the $\delta \circ \xi \alpha \zeta \epsilon I \nu$ of the Father $(\mathrm{vv} 1,4)^{\prime \prime}$. On the one hand, through Jesus' death on the cross ( $\mathrm{V} 1$; cf also 12:23-

${ }^{10}$ The content of this $\delta$ ó $\xi \alpha$ is to be interpreted and determined as the contrast of Jesus' life in the 'world below', for this $\delta \delta \xi \alpha$ concerns Jesus' existence in the 'world above'.

"In the Fourth Gospel the Father is seen as bringing glory to himself $(12: 28 ; 17: 5)$ or to the Son $(8: 54 ; 12: 16 ; 13: 32 ; 17: 1,5,10,22,24)$. He glorifies himself through the 
$24,27-28 ; 13: 31,32)$, which is the consummation of the ratification of $\dot{\eta}$ $\alpha i \omega \operatorname{vios} \zeta \omega \eta$, he glorifies the Father $(v \vee 1,2)$. But, on the other hand, in verse 4 the Father is glorified by the work Jesus completed (tò ह̌prov $\tau \in \lambda \in(\omega \sigma \alpha \varsigma)^{12}$ during his ministry, which is spelled out in more detail in verses 6-8. This $\delta 0$ $\xi \alpha$ relates to the revelation of the Father and his Son through the works, words and person of Jesus Christ, which culminate in the death of Jesus.

Apart from the primary theological setting, constituted by $\dot{\eta}$ $\alpha i \omega v i o s \zeta \omega \eta$, there are also two other theological settings (see previous paragraphs) to be considered in the understanding and interpretation of $\delta \circ \xi \dot{\alpha} \zeta \in t \nu$ which are closely interwoven with the primary setting $\dot{\eta}$

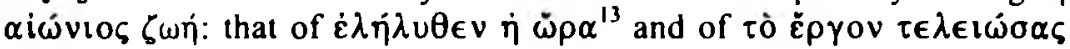

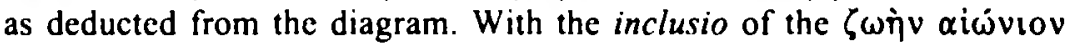
theme, a close relationship is laid between the $\delta \delta \xi \alpha$ motif and that of Jesus' mission ${ }^{14}$ to reveal the Father and accomplish salvation. This links

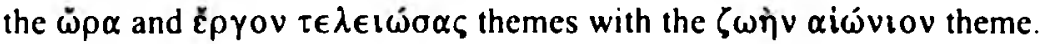

Although the glory of the Father and that of the Son have been split in the diagrammatical analysis in relation to the chiasm, they will be discussed simultancously since the 'glorification' of the Father and of the Son cannot be separated. The glorification of the one closely relates to the glorification of the other, and the glory of one constitutes the glory of the other.

\subsection{The theological context of the glorification in John 17:1-8:}

Scholars (Brown 1971:503; Painter 1975:50; Schnackenburg 1975:503; Aalen 1976:45ff; Kittel 1978:247ff; Cook 1984:292) agree that the Fourth Evangelist draws on the Old Testament idea of God's קברי In the

life, death and cxaltation of Jesus, for in the incarnate Son of God we have the most concentrated revelation of God. Likewise he glorifies the Son by helping him to complete his mission (Lindars 1981:518), and by restoring him to the position of honour and majesty that he occupied before the incarnation. According to Cook (1984:294) the glory of the Father and the Son are so closely related in the Fourth Gospel that it seems that the glory of the one equals the glory of the other $111: 4$; 16: 14,15$)^{\prime}$.

${ }^{12}$ According to the Fourth Gospel it is clear that Jesus' task on earth was to reveal and to redeem. In Jesus' report (17:1-8) we find explicit references to redemption ( $v v$ 2,3) and revelation ( $v v 6-8$ ), as well as implicit references to both in all these verses.

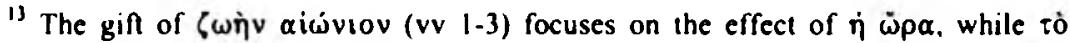

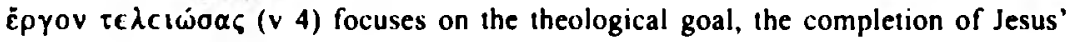
mission and the pre-existent glory of the Son (cf. Waldstein 1990:321).

'I In the continuation of Jesus' mission to the world the disciples of Jesus will not only contribute to the fact that people come to believe that Jesus is the Christ, the Son of (jod (20:31), but in this process they will also glorify God (see section 6.3). 
LXX, $\delta \hat{o} \xi \alpha$ is used to translate Hebrew term refers to that which is 'weighty' or 'impressive'.

Brown (1971:503) made a worthy contribution by high-lighting two important elements from the Old Testament in the under-standing of God's glory: "it is a visible manifestation of His majesty in acts of power. God manifests himself to men by striking actions (cf. Ex 16:7-10; $24: 17)$ '. When the word 'glory' is used with reference to God, it refers to the impact made on man by the self-manifestation of God (Cook $1984: 292)^{15}$. We can conclude that the $\delta \delta^{\prime} \xi \alpha$, whether used to refer to Jesus or to the Father, relates to 'revelation', i.e. a revelation of their identities through the striking acts of salvation which culminated in the crucifixion.

The LXX then becomes the significant background to the theological influence on the Fourth Evangelist's use of $\delta \delta \xi \alpha$ to refer to the 'honour' and 'glory' that come to God through the manifestation of his character (Cook 1984:292). The LXX (via Brown 1975 and Cook 1984) thus provides us with a scheme to closer determine the meanings of $\delta$ ó $\xi \alpha$ and $\delta \circ \xi a \zeta \epsilon t v$ in Chapter 17. When this scheme is applied to vv 1-8, it sounds as follows:

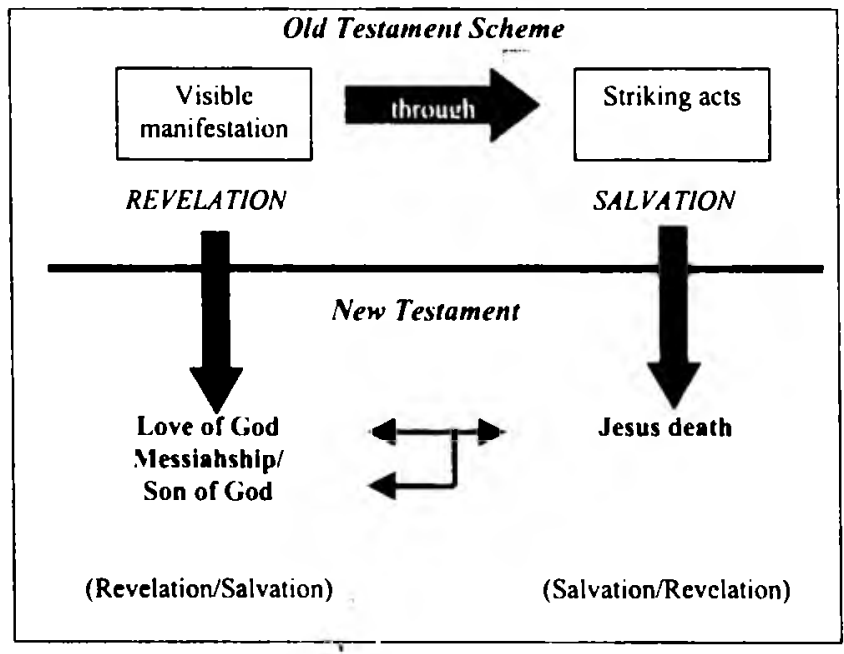

This Old Testament scheme closely relates to the theological construction of the 'glorification' of the Father and of the Son in the previous

\footnotetext{
15 Aalen (1976:48) disagrees with Cook and Brown. According to him '...glory is to be understood as a revelation of God, or as the intervention of his power in history $(1: 14 ; 2: 11 ; 11: 4 ; 12: 41)$, while in the opinion of Cook (1984) and Brown (1975) the acts of power are instrumental in the visible manifestation of God.
} 
diagram, where the components of both revelation and salvation appear. Although this scheme has its limits, it does provide a platform which, with some change, can be used in respect of Chapter 17. The Old Testament order of this scheme is also to be reversed here in the New Testament. In the Fourth Gospel, revelations about Jesus and God come first (see $\vee 6$ and $\vee 8$ ), and salvation follows when revelations are accepted. The contrary is also true in the Johannine perspective when Jesus brings about salvation on the cross and the love and justice of God and the Messiahship and Sonship of Jesus are revealed ( $v 1$ ).

The above discussion then implies that the two components that establish the glory of God in the Old Testament, i.e. the striking act of salvation, which leads to his revelation, relates to and helps to constitute the meaning of 'glorification' in John 17:1-5. Where the lexicons (linguistic and theological) help to determine the possible semantic fields of interpretation, the textual context indicates that the 'glorification' of the Father and of the Son are closely related and mutually constitute one another, while the theological context helps to indicate the 'glorification' as relating to God's soteriologic-christological acts of salvation and revelation. With this analysis we have constructed the basic semantic contours in which these terms are to be interpreted. A merging of the textual and theological contexts will help to determine the contextual meanings of $\delta \delta \delta \xi \alpha$ and $\delta \circ \xi \alpha \dot{\alpha} \epsilon t v$ more accurately (cf Vanhoozer 1998: $29 \mathrm{f})$. Hence, we will examine the specific statements about the 'glorification' of the Father and of the Son in relation to their theological settings.

\section{THE MERGING OF THE TEXTUAL AND THEOLOGICAI. CONTEXTS}

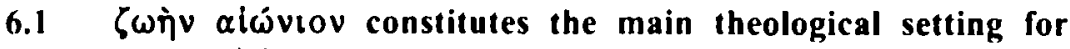 interpreting $\delta \circ \xi a ́ \zeta \epsilon t \nu$}

Jesus' petition for his own and the Father's glorification ( $v 1)$, and the reference to his contribution in giving life to men cannot be separated from one another (cf Waldstein 1990:321) ${ }^{16}$. This is evident in the ana-

${ }^{10}$ The theme of Chapter 17 is 'the continuation of the mission of Jesus by his disciples', and not 'the achievement of Jesus' aim', as Schnackenburg (1975:193) maintains with regard to verse 2 . In fact, these two themes should not be viewed as contrary to one another when considering the main theme of Chapter 17, but should rather be scen as complementary; as the continuation of Jesus' mission to give eter-

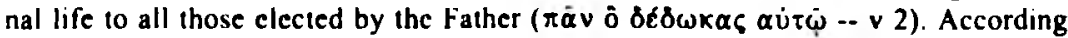
to Brown (1972:751) the giving of eternal life is intimalely related to the work that Jesus was doing in his earthly ministry ( $(4)$, and brings that work to completion, for Jesus' works were signs of his power to give eternal life. Bultmann (1941:376) 
lysis of the chiastic pattern of verses $1-5$ and the use of the particle of comparison, $\kappa \alpha \theta \omega \bar{\omega}$, in verse 2 .

Point $\mathbf{C}$ of the chiasm concerns the aim of the glorification of Jesus and that of the Father, that is to give $\zeta \omega \eta े v \alpha i \omega v i o v$ : iv $\alpha$

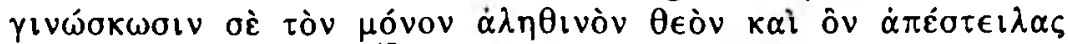

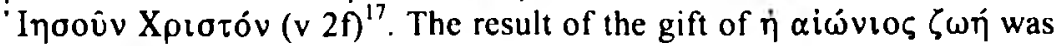
the glorification of the Father and of the Son. For the Son the giving of $\zeta \omega \eta \dot{v} \alpha i \omega$ viov was instrumental in the 'glorification' of the Father (v l),

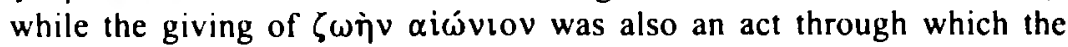
Son was 'glorified'.

Verse 2 provides some insight into the nature of the continuing glorification of the Father by the Son. According to Schnackenburg (1975:193; cf also Carson 1991:554) the linguistic construction of the $\kappa \alpha \theta \omega \varsigma$-clause with the iv $\alpha$-clause in the same verse (also found in 13:34; cf 13:15) can be best understood as a repetition and a clarification of the first iv $\alpha$-clause $(v \mid \mathrm{b})$, with an intervening causal clause ( $\kappa \alpha \theta \dot{\omega} \omega$ - 'in accordance with the fact that') ${ }^{18}$. Thus verse 2 establishes the basis for the petition of verse $\mathrm{Ib}$, and does so by establishing an analogical pattern (Carson 1991:554; also Barrett 1978:502).

There are also, according to Carson (1991:554), important horizontal parallels that can be observed. Verse 2 a refers to God's pre-temporal decision to give ${ }^{19}$ his Son authority ${ }^{20}$ over all people by virtue of

phrases the idea well when he says, "His work does not come to an end with his earthly life but in a real sense only begins with the end of that life'.

${ }^{17}$ Some scholars (Schnackenburg 1975:195) regard verse 3 as complementary to

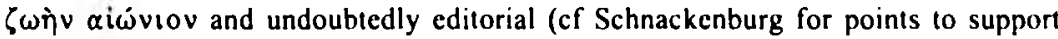
this point of view). Barrett (1978:503) views this verse as parenthetical but rejects Schnackenburg's point of view of 'a gloss'. Regardless of whether it is parenthetical or a gloss, the fact remains that this text is very important to understanding the theme of 'life' in the Fourth Gospel. The writer agrees with Barrett's statement (1978:503) that the Fourth Evangelist felt the necessity of a definition of cternal life and therefore incorporated it into the prayer.

18 Linguistically the second iva-clause is, according to Barrett (1978:502), partly purposive ('...gave him authority...in order that he might give ..'), partly explanatory ('...give him authority to give...'). The alternative is that iva may depend on

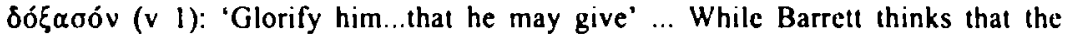
alternative possibility scems remote and less probable, Brown is of the opinion that the alternatives can be combined. According to Brown (1972:741) it is "better to recognize that the interpretations are not exclusive, and that to some extent the hina clause elaborates both antecedents. The granting of etcrnal life is the goal of the power over all men that has been granted to the Son ...; yet the granting of eternal life also constitutes the purpose for which the Son asks to be glorified'.

19 The repeated use of $8 i^{\delta} \delta \omega \mu l$ in Chapter 17 should not be overlooked (sec vv $4,6,7,8,9,11,12,14,22,24)$. This popular verb is found 76 times in the Fourth Gospel (Mt 56, Mk 39, Lk 60), of which 17 instances occur in Chapter 17. The Fourth 
the Son's prospective obedient humiliation, death, resurrection and exaltation $^{21}$ in order that (iv $\alpha$ ) the Son might give eternal life to those the Father has given him (Schnackenburg 1975:193f). It is nothing less than the redemptive plan of God, for the second part of verse 2 makes the purpose of this grant clear (Carson 1991:555). When Jesus asks that the Son might be glorified in order that he might in turn glorify the Father ( $\mathrm{V} \mathrm{Ib})$, it is congruent with the purpose clause in $v 2$.

\section{2 $\varepsilon \lambda \eta \dot{\lambda} \lambda \theta \epsilon v \dot{\eta} \bar{\omega} \rho \alpha$ a second theological setting for interpreting $\delta o \xi a ́ \zeta \epsilon t \nu$ in verse 1}

In understanding the cross as the occasion for the glorification of Jesus, it is essential to understand the use of the Greek word $\bar{\omega} \rho \alpha$ in verse 1 . At the beginning of this report $(v 1)$ by Jesus, the Agent, we read that the goal of his mission is $\dot{\eta} \bar{\omega} \rho \alpha$ of death and resurrection. Up to 12:23 the references to $\dot{\eta} \dot{\omega} \rho \alpha$ always denoted a future event $(2: 4 ; 4: 21,23 ; 7: 30$; 8:20), but here the parameters change when Jesus says: "... $\dot{\epsilon} \lambda \dot{\eta} \lambda u \theta \in v \dot{\eta}$

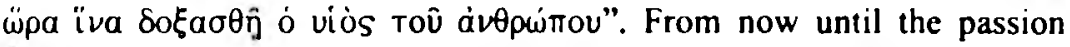
$\dot{\eta} \ddot{\omega} \rho$ is an immediate prospect $(12: 27 ; 13: 1 ; 17: 1)$. Also when Jesus

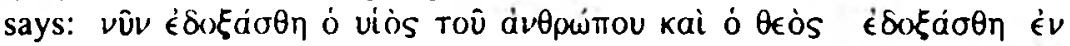
au่Tw? (13:31), he refers to his crucifixion as being imminent. The vivv refers to the 'hour' of Jesus' death. The Fourth Evangelist can use the aorist tense because, with the departure of Judas, all the actors in the drama, especially Jesus, are committed to their courses of action, which virtually make the crucifixion an accomplished fact.

Evangelist often uses the perfect tense 'denoting the permanence of the gift' (Morris 1971:718). Thirteen times the Father is the subject, with the gift having been made to the Son. The other four occasions refer to the giving of the Son to the disciples.

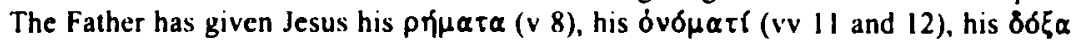
( $v v 20$ and 22) and his disciples (vv 2,6, 9,22). As the one who received everything from the Father, Jesus represents the Father.

${ }^{20}$ Éovoiav $(v 2)$ is the same noun that has been translated as 'the right' in $1: 12$. In both cases it is used in a soteriological sensc. This does not refer to Jesus' authority which he inherently enjoys through being the Son. This should make the Father's gift of authority to his Son equivalent to the fact that the Father is the fons divinitotis of the Son (Carson 1991:555; Schnackenburg 1975:1931). The Son's receiving of authority also does not proleptically refer to the gift of authority granted by the Father and consequently to the Son's obedience unto death as Schnackenburg (1975:193f; also Waldstein 1990:321) suggests. According to Newman \& Nida $(1980: 526)$ this is most likely the giving of authority to the Son as a prerogative of his carthly ministry.

21 The theological connection between resurrection and exaltation is not infrequent in the New Testament (c.g. Acts 2:32f; Rom 8:34; Eph 1:20; 2:6; Col 3:1; I Pet $1: 21$ ). John goes further, and theologically ties together the crucifixion, the resurrection and the exaltation. 
The $\check{\omega} \rho \alpha$ of Christ is also seen by the Fourth Evangelist as the supreme and unavoidable will of God. This $\check{\omega} \rho \alpha$ is the summit of the life of Christ, the most important accomplishment of Christ (Ramm 1963: 43). It was a divine imperative of the highest order. Jesus had to die $(\delta \in \hat{\imath}--3: 14 ; 12: 34)$ but at the time destined by God. In John 7:6, when his brothers request him to go to Jerusalem, Jesus tells them that their time is always here. His kaıpòs had been fixed by the will of the Father, and therefore would not come into existence until the time arrived that had been set by the rather (Ramm 1963:44). A study of $\ddot{\omega} \rho \alpha$ (and also kaıpòs in 7:6) indicates that the life of Christ was complctely determined and defined by the will of the Father. Nobody could arrest him before his hour. His life moved along its course according to $\dot{\eta} \check{\omega} \rho \alpha$ of the Father.

Thüsing (1970:99), who studied the $\check{\omega} \rho \alpha$ theme in the Fourth Gospel, observes that the employment of the two concepts $\dot{\omega} \rho \alpha$ and katpòs sets the entire earthly work of Jesus in relation to the event of his glorification. Through this dreadful $\tilde{\omega} \rho \alpha$ the Son of God is glorified ${ }^{22}$. From there $\dot{\eta} \dot{\omega} \rho \alpha$ for the return to the Father has to progress through the cross (13:1) (Ramm 1963:41f). This critical event was decisive for the salvation of mankind, because in this soteriological event the people would become aware of the true identity of Jesus (the Christ, the Son of God - 20:31), and, through this Christological event, also of the true

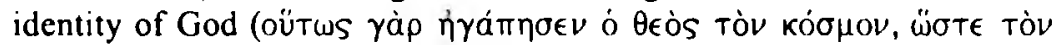

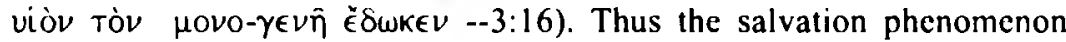
constitutes the revelation phenomenon as pointed out in the diagramme where the Johannine scheme of glory is compared and indicated to relate to that of the Old Testament. The cross is therefore not a revelation of glory as the transfiguration was, but the occasion for glorification (Ramm 1963:41). Thus $\dot{\epsilon} \lambda \dot{\eta} \lambda u \theta \epsilon \nu \dot{\eta} \dot{\omega} p \alpha$ constitutes the situation for the 'glorification' of the Father and Son.

\subsection{The $\delta \circ \xi a ́ \zeta \epsilon L \nu$ of the Son and the Father through the cross}

\subsubsection{The Son's glorification}

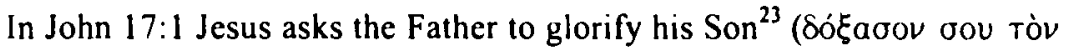
vióv). But the Fourth Evangelist introduces the verb $\delta \circ \xi \dot{\alpha} \zeta \in t v$ already in

22 Passages that refer to Jesus' hour are characterized by the same ambivalence as those referring to the "lifting up'. The hour of death $(7: 30,8: 20)$ is also the hour of glorification (17:1; cf 13:1,31--with vũv).

${ }^{23}$ Throughout his ministry Jesus possessed and manifested glory. In 1:14 it is stated that the Fourth Evangelist and others have seen Jesus' glory. At Cana Jesus revealed his glory to his disciples $(2: 11$; cf also $11: 4,40 ; 12: 28)$. His glory during his ministry was seen in his performance of signs. The cross was the ultimate sign in which his life-giving power was demonstrated. In the 'hour', the signs performed by Jesus 
$7: 39$, where he refers to the cross in terms of glory for the first time. Here it is clear that Jesus sees the cross and glory as one. This view is further developed by the Fourth Evangelist when he uses the verb iło $\omega^{24}$ ('lifted up'). In the Fourth Gospel this verb, which occurs in $3: 14 ; 8: 28$; $12: 32,34$, always involves the notion of being physically lifted up on the cross, with a suggestion of exaltation. The Fourth Evangelist was certainly influenced by the prophet Isaiah (Is 52:13 - 53:12, esp 52:13 LXX) (Kysar 1993:36f; cf. also Carson 1991:201), who linked the themes of 'being lifted up' and 'being glorified' in the context of the suffering servant. Schnackenburg $(1971: 498)$ states that the Fourth Evangelist starts from the outward event where Jesus is 'lifted up' (ivów) from the earth onto the cross, and gives it a transferred theological meaning. ${ }^{23}$ Carson (1991:201) explains it as a theological adaptation of the literal ('to lift up') and the figurative ('to enhance') meanings of the verb.

In John 3:13 Jesus refers to himself as the Son of Man who descended from heaven, but who will ascend to it again. This return to the glory, that he had with the Father before the world began (17:5), is accomplished by 'being lifted up' on the cross. In John 3:13 the Son of Man is characterized as the Revealer, the one who came down from heaven, while in verse 14 he is the exalted sufferer. The statement in John 3:14 expresses this return as the way in which it accomplished the will of God. He is the one who planned this crucifixion and will accomplish it (3:160). This is evident from the use of the passive (ivwenval) and the verb $\delta \in \hat{L}$, which is repeated in John 12:34. But Jesus also repeatedly states that he came to accomplish the will of the One who sent him, and in John 17:4 and 19:30 he refers to this will as having been fulfilled ( $\tau \in \lambda \in \mathcal{L} O \omega)$. Thus in verse 14 ir ${ }^{\prime} \omega \mathrm{w}$ reflects Jesus' total obedience, also suggested in the verb $\delta \epsilon \mathrm{L}$. This obedience of Jesus has to be distinguished from the obedience referred to in 17:4. In 17:1 his obedience

passed over to reality. After the crucifixion and exaltation his glorification continues through the granting of eternal life to all who believe in Jesus through the work of the Spirit (20:22) (cf Brown 1972:751).

${ }^{24}$ The Fourth Evangelist knows that Jesus must be crucified ( $\delta \in i \quad 3: 14 ; 12: 34$ ), but wants to play down the oxáv $\delta \alpha \lambda o v$ of the cross. In order to accomplish this he avoids references to the 'suffering' (the word $\pi \dot{\alpha} \sigma \alpha \in I V$ uccurs nowhere in the Fourth Gospel) and describes this event in Jesus' experience as 'glorification' (13:31f; $17: 1$; of $7: 39 ; 12: 16)$. In support of this idea he pictures Jesus' crucifixion as an experience of being lifted up from the earth $(3: 14 ; 8: 28 ; 12: 32,34)$. "The "glorification" of Jesus in the Passion was the Divine acceptance of His Sacrifice by the Father, the sealing of His Mission as complete' (Bernard 1963:560).

${ }^{25}$ This concept, which has its roots and ramifications in Johannine theology as a whole, has already been thoroughly examined by Thüsing (1970). Cf also Moloney (1976) 'The Johannine Son of Man'. 
to the Father's will is the means in itself (see section 6.2), while in verse 4 it constitutes the way to attain his glorification, even though the cross is anticipated here. From these two verses it comes to light that it is in the matrix of suffering and exaltation that God most clearly reveals himself in the person of his Son (Carson 1991:201).

The double force of the verb útów is maintained in $8: 28$. The Fourth Evangelist tries to indicate that another function of the cross is to reveal who Jesus is. The statement here concems the realization of Christ's identity. The verb ( $\gamma \nu \omega \sigma \in \sigma \theta \epsilon)$ and the $\dot{\epsilon} \gamma \dot{\omega} \in \dot{i} \mu \mathrm{l}$-saying confirm this. Jesus' 'glory' will be most fully revealed when he is lifted up. When he is 'lifted up' on the cross, he is being lifted up to his Father's presence. It is this event that establishes Jesus' claim most forcefully:

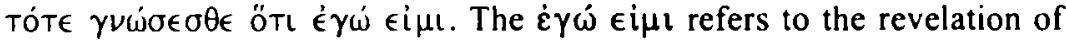
Jesus' divine dignity (as the Christ, the Son of God -- 20:31). Here the Son identifies himself with the Father in divine terms. Verse 8:29 qualifies $\dot{\varepsilon} \gamma \dot{\omega} \epsilon i \mu \mathrm{l}$. Jesus can say $\dot{\varepsilon} \gamma \dot{\omega} \epsilon \dot{\mathrm{i}} \mu \mathrm{l}$ because ò $\pi \dot{\varepsilon} \mu \psi \alpha \varsigma \mu \epsilon \mu \epsilon \tau^{\prime} \dot{\varepsilon} \mu o \hat{v}$ $\dot{\varepsilon} \sigma \tau \imath$. This refers to the unity between Father and Son. Jesus' profound sense of the Father's presence is the direct consequence of his perfect self-conscious submission to the will of his Father (Carson 1991:345).

In 12:34 the Fourth Evangelist combines the two statements made

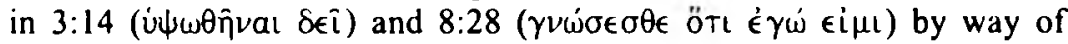
letting the crowd ask a double question concerning the Son of Man.

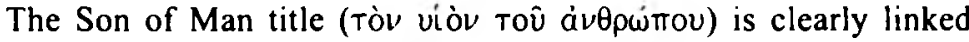
with Jesus' exaltation. In three of the four texts $(3: 14 ; 8: 28 ; 12: 34)$ Jesus

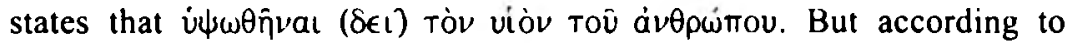
$12: 34$, the crowd does not understand Jesus' reference to himself as the Son of Man in 12:23 as a messianic claim. This lack of understanding reflects the high frequency of misunderstanding and lack of understanding of Jesus' disciples, the crowds and the Jews about Jesus' teaching concerning himself $f^{26}$. This is the reason for their two questions in verse 34 , because not everyone in Palestine could have made a confident connection between 'Son of Man' and 'Messiah'. According to 8:28 will they know that Jesus is the Messiah when he is exalted. This will draw all men to Christ (12:32).

From these four texts it is clear that the verb iłoow is used by the Fourth Evangelist to link Jesus' death with his glorification. It is used to

26 Misunderstandings on the part of the disciples are evident in $4: 31-33 ; 11: 11-15$ and on the part of other people in 2:19-21 (Jews); 3:3-9 (Nicodemus); 4:10-15 (Samaritan woman); 6:32-35 (crowd); 6:51-53 (Jews); 8:21-27 (Jews); 8:32-33 (Jews); 8:56-58 (Jews); 9:39-40 (Pharisees); 11:23-25 (Martha); 12:32-34 (crowd). Lack of understanding in the case of the disciples may be observed in $4: 34 ; 6: 6$ $7,19,60-61 ; 9: 2 ; 11: 14,16 ; 12: 1-8,16(12: 20-26$ by implication; cf. $10: 6)$, and in the case of the Jews $5: 17-18 ; 6: 40-43,51-52 ; 7: 33-36 ; 7: 21-22 ; 8: 18-19,24-27 ; 10: 30-33$. 
refer to Jesus' exaltation on the cross and so reflect his glorification through: (1) Jesus' obedience to the Father's will (reflected in the verb $\delta \in \hat{\imath}-3: 14 ; 12: 34)$; (2) the revelation of Jesus' identity ${ }^{27}$ (reflected in the $\dot{\epsilon} \gamma \dot{\omega} \epsilon i \mu \mathrm{t}-8: 28)$, and (3) the attraction of people 'to him', which means 'to salvation' (12:32). Therefore, in the light of the above discussion concerning Jesus' glorification in $v 1, \delta \delta \xi \alpha \sigma o ́ v$ can be substituted by the verb i $\psi \dot{0} \omega$, used in a pregnant sense, which can then be translated as 'exalt your Son on the cross' (as a striking act of salvation) (cf Groene wald 1980:344) in order to recall the above three statements made in connection with ư $\psi$ ów.

\subsubsection{The Father's glorification}

The petition presented by Jesus in $\vee 1$, " $\delta$ ó $\xi \alpha \sigma o ́ v$ oou tòv vióv", con tains as its prime motivation: "iva ó viòs $\delta o \xi \dot{\alpha} \sigma \eta \underline{\sigma \varepsilon}$ ". This petition makes it clear that the Son's glorification here is also the glorification of the Father: the one does not exist without the other (cf. 14:9-11). This 'glorification' of the Father can only be realized when the Son is 'glori fied' (iva with aorist subjunctive $\delta \circ \xi \alpha$ an), which is accomplished öTav

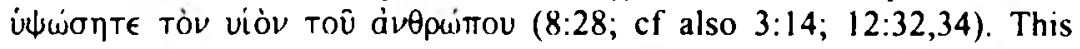
critical event was decisive for the salvation of mankind, because it

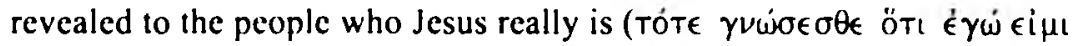
- 8:28) and, through this Christological event, who God is. Thus the salvation phenomenon constitutes the revelation phenomenon. God has now revealed his identity clearly by what he achieved on the cross, namely the exaltation of his Son.

The 'glorification' of the Father $(v 1)$ is even better understood

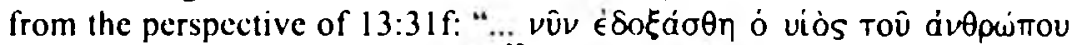

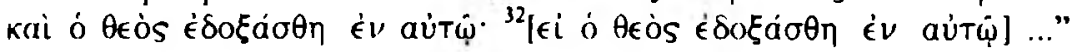
Caird (1969:265ff) has shown that the aorist passive "É $\delta \circ \xi \alpha \sigma \theta \eta$ " here was the expected way to translate the Masoretic Text's use of the niphal of the verb majesty of God in acts of power. Here we can recall Isaiah 49:3, where God addresses the Servant of the Lord: 'You are my servant, Israel, in whom I will display my splendour'. But Jesus transcends Israel's role. In his exaltation, Jesus is glorified, i.c. God's splendour is displayed. Therefore the phrase "iv $\alpha$ ó viò $\zeta \delta \xi \dot{\alpha} \sigma \eta \emptyset \tilde{\varepsilon}$ " ( $\mathrm{v} 1$ ) can be translated as 'that the Son may reveal your majesty / splendour or greatness ...' (cf. 17:6-8).

27 The Fourth Evangelist probably regards the death of Jesus as above all a demonstration of his Messiahship (cf. 20:31). Thus, in the passion narrative, just as in the first half of the Fourth Gospel, the emphasis is predominantly Christological. The Messiah brings salvation by his very presence; by belicving in Jesus as the Messiah we receive salvation. 


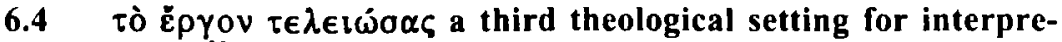 ting $\delta \circ \xi \alpha ́ \zeta \epsilon \nu^{28}$ in verses 4-5}

The sending of the Son in the Fourth Gospel is closely linked with the glorification of the Father. The sent one is commissioned: to bring glory and honour to the sender $(5: 23 ; 7: 18$; $\operatorname{cf} 13: 31 \mathrm{f} ; 17: 1,4)$; to be obedient to the sender's will $(4: 34 ; 5: 30,38 ; 6: 38 f)$ and works $(5: 36 ; 9: 4 ; 17: 4)$, and to speak the sender's words $(3: 34 ; 7: 16 ; 12: 49 ; 14: 10 \mathrm{~b}, 24)$. Jesus claims that his sender's glory is the foremost concern of his mission (cf $11: 4,40 ; 12: 28 ; 13: 31 ; 14: 13 ; 17: 1,4,5)$ (Köstenberger 1998:108).

The work to which Jesus refers in his report to the Father as completed, in verse 4 , is the revelatory-salvific task he had to perform ${ }^{29}$. In verses 2 and 3 he refers to his salvific work on the cross (anticipated in

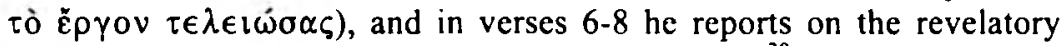
work successfully accomplished during his ministry ${ }^{30}$ (see also footnote 29).

In verses 6 and $8^{31}$ Jesus' task of revelation is phrased in terms of

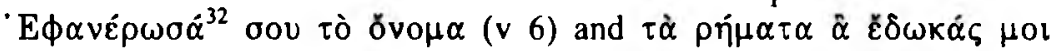

${ }^{28} \alpha i \omega \dot{v i o \zeta} \zeta \omega \grave{\eta}$ is not mentioned in verses 6-8 but certainly links with 17:1-5. Verses $6-8$ is an explanation of tò épyov $\tau \epsilon \lambda \in i \omega \sigma \alpha \varsigma$ in verse 4 and $\delta \dot{\omega} \sigma \eta$.

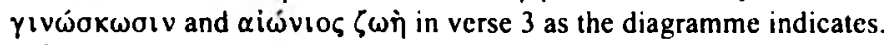

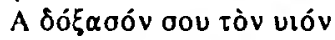

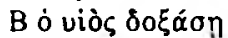

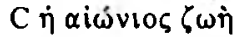

B' $\varepsilon \gamma \omega$ oe $\dot{\varepsilon} \delta \delta \hat{\xi} \alpha \sigma \alpha$

$A^{\prime} \delta o ́ \xi \alpha \sigma o ́ v \mu \epsilon$ oú

29 According to Morris (1971:720) the phrase $\dot{\varepsilon} \gamma \dot{\omega}$ oє $\dot{\varepsilon} \delta \delta \hat{\xi} \alpha 0 \alpha$ ( $(\mathrm{v}$ 4) indicates a

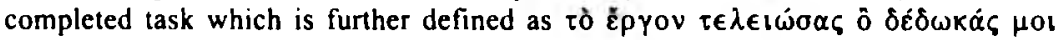
iv $\alpha \pi 0$ เทं $\omega$. Morris also asserted that the juxtaposition of the two pronouns $\dot{\varepsilon} \gamma \dot{\omega}$ and $\sigma \in$ points to the fact that the mission of Jesus was solely to glorify God through his work.

30 Thüsing (1970:100) is of opinion that $\dot{\eta} \dot{\omega} \rho \alpha$ and tò $\check{\varepsilon} \rho \gamma o v \quad \tau \in \lambda \in l \omega \dot{\omega} \alpha \varsigma$ are closely bound together. According to him the hour of glorification is the hour of the completion of the work. Verses $2 f$ refer explicitly to the salvatory work of Jesus, but imply revelation as the result of salvation, while in verses $6-8$ the revelatory work of Jesus is emphasized and salvation is seen as the result of the revelation. Salvation and revelation cannot be interpreted separately for they are complementary to one

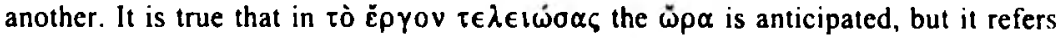
more explicitly the Jesus' ministry as spelled out in verses 6-8.

${ }^{31}$ Verses 6-8 relates to the acceptance of the revelation brought by Jesus to the disciples. Linguistically verse 8 is causal ( $\delta \tau t$-clause) to verse 7 , but on the theological level verses $6-8$ contain two equal subdivisions ( $v$ v 6,7 and $\vee 8$ ) which mould into a theological parallelism.

We can say that these two subdivisions form a symmetric parallelism and mutually cxpose one another. In both subdivisions there is a theological development from the point of revelation ( $v \vee 6,8)$ to the point of responsc by showing obedience $(\mathrm{vv} 6,8)$, 


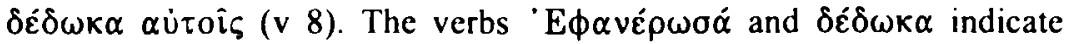
both the deed of revelation (by Jesus) and the content of revelation (through Jesus). Jesus is the only one who really knows God. In John $1: 18$ it is said that the Son is at the Father's side. Therefore Jesus said that if we want to know God, we can achieve this only through him, because he is the only way to God (14:6), who 'has made him known'

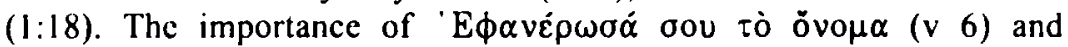

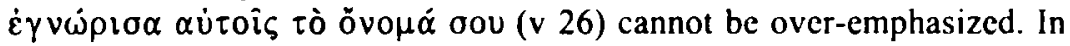
both cases it is stated that the Son has 'revealed/made known the Name of the Father'. These two references are the only two places in the Fourth Gospel where Jesus is explicitly reported to have revealed the name of God to men (Brown 1972:754). The revelation of the Father's name becomes clearer when these two phrases are compared.

What does the Fourth Evangelist mean with this expression? ${ }^{33}$ The expressions in 17:11,12.26 indicate that the interpretation of the phrase in verse 6 goes beyond a literal interpretation. According to Newman and Nida (1980:530) the reference to "tò óvo $\mu \alpha$ " of God is another way of referring to God himself. According to Schnackenburg (1975:199;

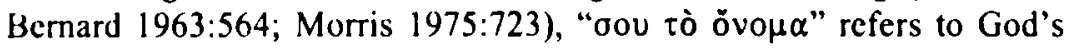
being and nature, his holiness, justice and love (the disclosure of God himself -- Bultmann 1941:381), which are certainly expressed in the

to the implication of acceptance of this revelation in faith ( $\vee 7$ and $v 8$ ). Each subdivision starts with a statement of revelation, followed by a response introduced by a copulative particle $k \alpha i$, to end in a confession of faith introduced by a òt particle.

${ }^{2}$ According to Lenski (1961:1128f). "The aorist records the accomplished fact while the verb фavépoúv is comprehensive, "make visible and clear," ... somewhat like "to reveal" by alt that Jesus is, says, and does.' Barretl (1978:505) and Carson

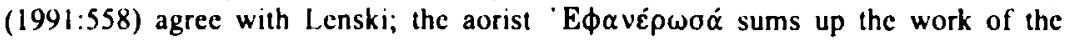
ministry of Jesus. According to Carson it also includes the cross. The verb

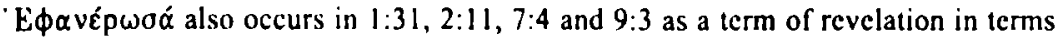
of the manifestation of Jesus, his glory and the works of God.

${ }^{33}$ Brown (1972:755f) and Dodd (1980:417) seem to be on the wrong track when

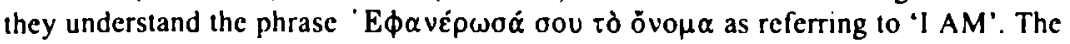
idea here is not that Jesus is thinking in terms of a specific name for God (Barrett 1978:505). The previous section on Jesus' agency has produced no indication of the revelation of a specific name for (jod. Scholars are in a sense unanimous in their opinion that this revelatory formula concerns only the revelation of God. Bultmann (1941:381; cf L.enski 1961:1129) interprets the communication of the divine name as the disclosure of God himself, which is the disclosure of the $\dot{\alpha} \lambda \dot{\eta} \theta \epsilon \iota \alpha$. Lindars (1981:521) correctly speaks of the 'character of the Father'. Bultmann's reference to

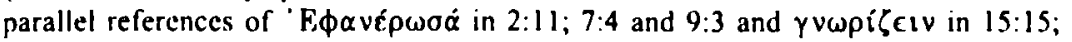
17:26 supports the interpretation of l.indars that it refers to the "character of the liather'. According to Barrett (1978:505), Jesus' manifestation of God's name is his declaration of the invisible (iod $(1: 18)$. 
address to the Father and the attributes connected with the name. Sanders \& Mastin (1975:369) and Carson (1991:558) are of the opinion that it refers to the character and identity of God which were proclaimed throughout the ministry of Jesus and which included even the cross. This description of God's character and identity was given to Jesus by God himself ( $(\mathrm{v} 8$; also 12:50). Therefore oou tò ỏvo $\alpha \alpha(v 6)$ is nothing other than $\tau \grave{\alpha} \rho \eta \dot{\mu} \alpha \tau \alpha(\mathrm{v} 8)$, which God gave to Jesus; both refer to the revelation that comes through Jesus (Newman \& Nida 1980:531).

\subsection{The $\delta \circ \xi a$ $\zeta \epsilon t v$ of the Father and the Son in the completion of Jesus' mission}

\subsubsection{The Father's glorification}

Jesus, in reviewing his earthly mission, declares that he has accomplished the task the Father assigned to him (v 4), and through this has glorified ( $\dot{\varepsilon} \delta \delta^{\prime} \xi \alpha \alpha$ ) the Father. He glorifies the Father by always obeying His will. Christ's entire life revolves around doing the works of God to the glory of God. Christ says that his food is to do the will of the Father who sent him and to accomplish his work (4:34); that his works are the works of God manifest in him (9:3); that the works he does prove his special unity and union with the Father (10:38); that the Father within him does his works (14:10); and that at the end of his life he has completed and fulfilled the work of the Father referred to in 17:4 as "to ع́pyov $\tau \epsilon \lambda \epsilon i \omega \sigma \alpha \zeta "$ (cf also 19:30), but spelled out in 17:6-8 as the revelation of the Father's identity (sce section 6.4).

We see the earthly activity of Jesus is aimed at revealing the character of the Father, to make known his divine glory (Lindars 1981:521). Jesus himself is the revelation and the glory of God, the visible manifestation of the invisible God, the only way to the Father. His incarnation, his teaching, his miracle-working, his encounters with people, yes his entire life, are placed within the all-embracing context of revelation. Through all this he brings to mankind the distant and totally other God. In the context of $\delta \circ \xi \alpha$, Christ is the dwelling place of God among men (Jn 1:14), the image of God (12:45; 14:9) (cf Schnackenburg 1971:511).

It can be stated confidently that the phrase tò $\check{\varepsilon} \rho \gamma o v \tau \in \lambda \in \imath \omega \dot{\omega} \alpha \varsigma$ clearly relates to verses $6-8$, which reflect the essence of Jesus' ministry

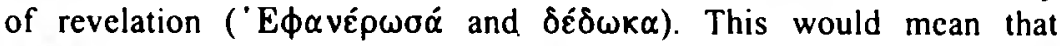
$\delta o \xi \alpha \zeta \measuredangle \in t \nu$ in verse 4 can be taken as referring to Jesus' obedient revelation of the Father's identity (oov tò ővo $\mu \alpha[\mathrm{v} 6]$ and $\tau \dot{\alpha} \rho \dot{\eta} \mu \alpha \tau \alpha \hat{\alpha}$

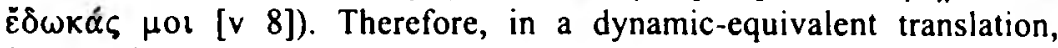

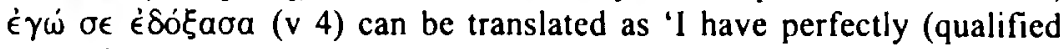
by $\tau \in \lambda \in i \omega \sigma \alpha \varsigma)$ revealed your identity and greatness' (see vv 7-8). 
Because of the close relationship between the 'glorification' of the Father and that of the Son is the identification of the Father's identity here an allusion of the Son's glorification.

\subsubsection{The Son's glorification}

According to these texts it seems clear that the work of the Father is also that of the Son; the Son glorifies the Father through his complete obedience to Him, while the Father glorifies the Son in recognition of his obedience. Throughout the Fourth Gospel Jesus' claims and behaviour are the fruit of obedience to the Father (cf $3: 34 ; 5: 19 \mathrm{ff} ; 8: 38 ; 17: 8,14$ ). By always saying and doing only what the Father instructs him to say and do, he honours the Father (Carson 1991:355). But in verses 4 and 5 it becomes clear why Jesus should be glorified in the light of what he has already done -- he has completed the task assigned to him by the

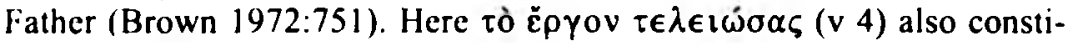
tutes the setting from which his glorification has to be interpreted. Where tò $\check{\varepsilon} \rho$ yov $\tau \in \lambda \in \imath \omega \sigma \alpha \varsigma$ of the Son is the means to glorify the Father, constitutes it the way to attain his glorification.

Here a new perspective is added to the $\delta \delta \xi \alpha$ motif. The second part of verses 1-5 does not interpret Jesus' hour as does the first part, namely in terms of its effectiveness in giving life, but in terms of its

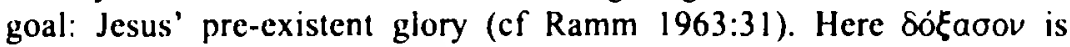
closer determined by $\tau \hat{\eta} \delta \delta \hat{\eta} \eta \hat{\eta}$ in the same verse by the reflexive pronoun $\sigma \epsilon a \cup T \bar{\varphi}$. The glory referred to in $v 5$ is neither the glory manifested in the earthly life of Christ $(1: 14)$, nor the glory given by virtue of Jesus' passion (Phil 2:9-11), but a unique pre-creation, pre-temporal glory ${ }^{34}$. This glory Jesus implores the Father to allow him to establish is his original glory with him. This is emphasized by the use of the preposition $\pi \rho o$ (before) in verses 5 and 24. This glory forms part of the divine redemption, which is a cooperative work of the Father and Son (Ramm 1963:31).

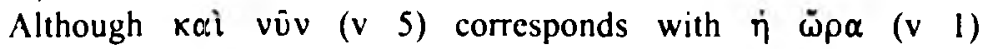
(Schnackenburg 1975:197) it announces a new relationship between persons (Laurentin 1964:195). The decisive turning point indicated by

\footnotetext{
34 In order to interpret the pre-existent $\delta \delta \xi \alpha$, Waldstein (1990:322f) uses the wrong text in Chapter 17. He is of the opinion that the oneness motif in Chapter 17 refers to the ontological unity that exists between the Father and the Son. From the perspective of this oneness he tries to explain the pre-existent $\delta \delta \xi \alpha$. The oneness motif in Chapter 17 refers rather to the functional unity between the Father and the Son Barrett (1978:429) refers to this glory as '..the glory of Christ within the Godhead, his glory as (iod'. Bernard (1963:563) agrees with Barrett: 'The glory of the Eternal Word is distinguished from the glory of the Incarnate Word ... the spheres of life are different [i.e the first is in the Godhead; the second, on earth]'.
} 
these two temporal signs ( $\kappa \alpha \grave{\imath} v \hat{v} v^{35}$ ) shows that the moment of departure

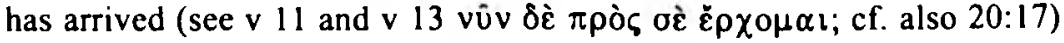
(Schnackenburg 1975:197).

Furthermore, the noun $\pi \dot{\alpha} \tau \in \rho(\vee 5)$ emphasizes the intimate relationship between Jesus and the Father (cf Groenewald 1980:346), and gives an indication of how this heavenly $\delta$ ó $\xi \alpha$ should be interpreted. In this text ( $v 5$ ) the emphasis is on the glorious state that Christ will regain, the glory that belongs to him $(1: 14 \mathrm{~b})$ and which he previously experienced (see 6:62); thus quite a different type of interpretation must be employed (cf Newman and Nida 1980:529). The $\delta$ ó $\xi \alpha$ in verse 5 refers to the heavenly glory of Christ (Barrett 1978:504). By using the phrases $\pi \alpha \rho \grave{\alpha} \sigma \epsilon \alpha \cup \tau \hat{\varphi}$ and $\pi \alpha \rho \grave{\alpha} \sigma o i$ (v 5) Jesus indicates that he wants to return to the position he enjoyed before the incarnation, that the eternal glory that he enjoyed before the incarnation (cf 1:1) may be resumed in fellowship with the Father (Bernard 1963:563; Brown 1972:742). This majestic 'glorification' of Christ reveals his person, and elucidates his ability to bring salvation on the cross and explains why his example can be imitated.

He is 'the only Son' who occupies the place of intimacy and honour next to the Father $(1: 18)$. Jesus repeatedly affirms that he has descended from God, from heaven to earth $(3: 13,31 ; 6: 33,38,46 ; 18: 37)$; he is from above, he is not from the earth $(8: 23)$; he has come from the Father and has arrived in the world (16:27f); and he now leaves this world and returns to his Father in heaven $(13: 1 ; 16: 5,10 ; 16: 28)$. Probably the most compelling evidence in the Fourth Gospel is found in the passages where he applies the divine name 'I AM' to himself $(6: 20$; $8: 24,28,58 ; 13: 14)$. The most dramatic instance is this statement to the

${ }^{35}$ Scholars interpret (Kai) vūv differently. Barrett and Newman and Nida interpret it as having a theological meaning. The phrase $k \alpha \grave{\imath}$ vûv $(v S)$ is used by the fourth Evangelist to strengthen the request of Jesus made in verse 1 (Newman \& Nida 1980:528f). The Fourth Evangelist also uses the vúv (v 5), the aorist imperative and the juxtaposed pronouns to bring out a contrast in verse 5 : 'In his obedient ministry Jesus has glorified the Father; now, in response to the death which sets the seal upon his obedience and his ministry, let the Father glorify him' (Barrett 1978:504; cf. Newman and Nida 1980:529). Schnackenburg and Bernard give it a temporal meaning. Barrett's interpretation, in which Jesus' glorification is presented as a reward for his obedience, is unacceptable. Jesus did not deserve or carn the heavenly glory he is asking for, instead it is part of his nature, he always possessed it (Sanders 1975:369). Laurentin (1964:425 quoted by Brown) points out that kai vûv can introduce a more decisive repetition of a request already made. Brown is of the opinion that this seems to be the function in the present context if verse 1 and verse 5 are compared. This is acceptable only if the content of the glorification is not considered. 


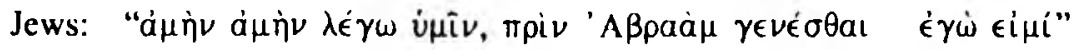
(8:58).

In conclusion we can state that the meaning of $\delta \xi^{\prime} \xi \sigma o v$ as it is used in verse 5 is closely determined by $\delta$ ó $\xi \alpha$ in the same verse. This $\delta$ ó $\alpha$ relates to that in verse 24 and concerns the status (majesty/honour) Jesus enjoyed with the Father before creation. Therefore, "Kat vûv

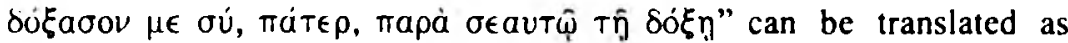
"And now, Father, honour me/clothe me in your presence with the same majesty / greatness' (that I possessed before the earth was created).

\section{CONCLUSION AND PROPOSED TRANSI,ATION}

From the above analysis it is clear that $\delta 0 \xi a \xi \epsilon t \nu$ cannot express the whole meaning of glory. In each text where $\delta \circ \xi \alpha$ a $\zeta \in V$ is used a specific semantic meaning is in focus and is more important than the others. When translating $\delta \circ \xi \dot{\alpha} \zeta \epsilon \mathrm{V}$ into another language, the first task of the translator is to discover which component of its meaning is the most important in the particular context in which it is used. Once clarity has been achieved in this regard. he will be in a position to choose the equivalent term that best expresses the meaning of $\delta 0 \xi \alpha \zeta \epsilon t v$ in that text. Note that the equivalent term that is best in one text will not necessarily be the best in another text.

It is clear that in Chapter 17 giving and showing glory is one of the main themes. Here the Fourth Evangelist uses the verb $\delta \circ \xi a$ $\zeta \epsilon I V$ in more than one way, as he does with other important words in other parts of his gospel. On the one hand we see the situation on earth where Jesus shows God's glory (identity) ( $v$ l) through his exaltation (his glorification) on the cross. On the other hand we get the picture of heaven where Jesus shares in the heavenly glory (majesty) of his Father due to his disclosure of the Father's identity and greatness through his obedience to his will.

The proposed translation would be suited only to a dynamic-equivalent or periphrastic translation of the text. On the basis of the above analysis, the following translation of $\delta o \delta \xi \alpha$ and $\delta \circ \xi \alpha \dot{\alpha} \epsilon t v$ in John 17:1-5 can be proposed:

' $\delta o ́ \xi \alpha o o ́ v$ oou tòv vióv - Exalt your Son on the cross

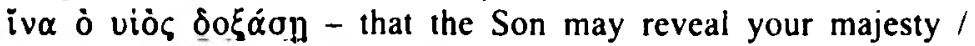
greatness

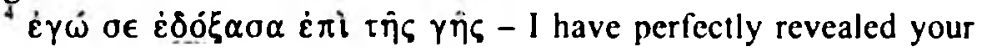
identity and greatness on carth

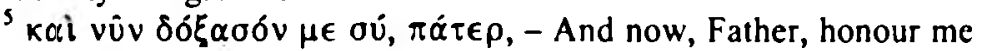
/ clothe me in your presence (in splendour)

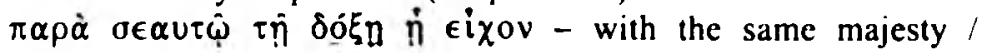
greatness that I posessed.... 


\section{Consulted literature}

Aalen, S 1976. Glory, honour, in: Brown, C (ed). DNTT. Grand Rapids: Eerdmans.

Barrett, C K 1978. The Gospel according to St John. London: SPCK.

Bernard, J H 1963. Gospel according to St John. A Critical and exegetical commentary (Vol 2). Edinburgh: T \& T Clark.

Blass, F \& Debrunner, A 1974. A Greek grammar of the New Testament and other earlv Christian Literature. Chicago: The University of Chicago Press.

Bratcher, R G 1991. What does 'Glory' mean in relation to Jesus? Bible Translator 42 (4) $401-408$.

Brown, C 1976. Dictionary of New Testament Theology. Grand Rapids: Eerdmans.

Brown, R E 1971. The Gospel according to John (i-xii) (The Anchor Bible). London: Gcoffrey Chapman.

-, R E 1972. The Gospel according to John (xiii-xxi) (The Anchor Bible). London: Geoffrey Chapman.

-, R E 1975. The Gospel according to John (i-xii) (The Anchor Bible). London: Geoffrey Chapman.

Bultmann, R 1941. Das Evangelium des Johannes. Göttingen: Vandenhocck und Ruprecht.

- R 1971. The Gospel of John. Oxford: Basıl Blackwell.

Caird, G B 1969. The Glory of God in the Fourth Gospel: an exercise in Biblical Semantics. New Testament Studies 15:265-77.

Carson, D A 1991. The Gospel According to John. Lcicester: Inter-Varsity Press.

Cook, W R 1984. The 'Glory' motif in the Johanninc Corpus. Journal of the Evangelical Theological Society 27:291-297.

Danker, F W (ed) 2000. A Greek-English Lexicon of the New Testament and other Early Christian Literature. Chicago: University of Chicago Press.

Dodd, C H 1980. The Interpretation of the Fourth Gospel. London: Cambridge University.

Fry, E 1976. Translating 'Glory' in the New Testament. Bible Translator 27:421425.

Groenewald, E P 1980. Die Evangelie van Johannes. Kaapstad: N.G. Kerk-uitgewcrs.

Hegermann, H 1990a. $\delta \delta \xi \alpha$ in: Balz, H \& Schncider, G (cds). Exegetical Dictionary of the New Testament. Grand Rapids: Eerdmans.

-, H 1990b. ठo $\xi \hat{\alpha} \zeta \omega$ in: Balz, H \& Schneider, G (cds). Exegetical Dictionary of the New Testament. Grand Rapids: Eerdmans.

Hill, D 1967. The request of Zebedic's Sons and the Johannine $\delta$ ó $\xi \alpha$-theme. New Testament Studies 13:281-285.

Ibuki, Y 1988. 'Die Doxa des Gesanden - Studic zur johanneischen Christologie,' in Sekine, M \& Satake, A (eds) Annual of the Japanese Biblical Institute (Vol 14). Tokyo: Yamamoto Shoten, 38 -81.

Käsemann, E 1968. The Testament of Jesus. A Study of the Gospel of John in the light of Chapter 17 (Translated by G Krodel). London: SCM.

Kittel, G 1935. $\delta o ́ \xi \alpha$, in: Kittel, G (Hrsg). TWNT (Band 2). Stuttgart: Kohlhammer.

Köstenbergr, A J 1998. The mission of Jesus \& the disciples according to the Fourth Gospel. Grand Rapids: Eerdmans

Kysar, R 1993. John (The Maverick Gospel). Louisville: John Knox Press. 
Laurentin, A 1964. 'We'attah - kai nun. Biblica 45:168-432.

Lenski, R C H1 1961. The interpretarion of St John's Gospel. Utah: Provo.

Liddell \& Scott 1974. Greek-English Lexicon. Oxford: The Claredon.

Lindars, B 1981. The Gospel of John (The New Century Bible Commentary). Grand Rapids: Eerdmans.

Louw, J P \& Nida, E A 1988. Greek-English lexicon of the New Testament based on semantic domains (Vol 1). New York: United Bible Societies.

Malatesta, E 1971. The literary structure of John 17. Biblica 52:190-214.

Minear, P S 1978. John 17:1-11. Interpretation 32 (2):175-179.

Moloney. F J 1976. The Johannine Son of Man. Biblical Theology Bulletin 6:177189.

Morris, L 1971. The Gospel According to John (The New International Commentary on the NT). Grand Rapids: Eerdmans.

Newman, B M \& Nida, E A 1980. A Translators handbook on the Gospel of John London: United Bible Societies.

Nida, E A \& Louw J P 1988. Greek-English Lexicon (Vol 1). New York: United Bible Socicties.

Painter, J 1975. John: Witness \& Theologian. London: SPCK.

Pamment, M 1983. The meaning of doxa in the Fourth Gospel. Zeitschrift für die Neutestamentliche Wissenschaft und die Kunde des Urchristentums 74:12-16.

Ramm, B 1963. Them He Glorified (A systematic study of the doctrine of glorification). Grand Rapids: Eerdmans.

Ridderbos, H 1997. The Gospel of John. Grand Rapids: Eerdmans.

Robbins, V K 1996. Exploring the texture of texts. Harrisburg: Trinity Press International.

Sanders, J N \& Mastin, M A 1975. The Gospel According to St. John Blacks' New Testament Commentaries. London: Adam and Charles Black.

Schnackenburg, R 1975. Das Johannesevangelium (III Teil). Kommentar zu Kap. 13-21. Freiburg: Hazel.

Thüsing, W 1970. Die Erhöhung und Verherrlichung Jesu im Johannesevangelium. Münster: Aschendorff.

Ukpong, J S 1989. Jesus's Prayer for his Followers (Jn 17) in Mission perspective. Africa Theological Journal 18 (1):49-60.

Vanhoozer, $\mathrm{K} J$ 1998. Is there meaning in this text? Grand Rapids: Zondervan.

Waldstein, M 1990. The Mission of Jesus and the disciples in John. Communio. International Catholic Review 17 (3):31 1-333. 